\title{
PENGARUH KUALITAS PELAYANAN DAN PROMOSI TERHADAP KEPUTUSAN PEMBELIAN MCDONALD'S TAMAN PINANG SIDOARJO DI MASA PANDEMI COVID-19
}

\author{
Ririn Istighfarin', Aura Fitriani² ${ }^{\text {, Nadya Lizza Riyani Hapsyah }}{ }^{3}$ \\ Universitas Islam Negeri Sunan Ampel 1,2,3 \\ $\underline{\text { ririnistighfaring9@gmail.com }}$; aurafitriani2000@gmail.com $^{2} ; \underline{\text { nadyalizza9@gmail.com }}{ }^{3}$
}

\begin{abstract}
ABSTRAK
Penelitian ini bertujuan untuk mengetahui dan menguji pengaruh variabel kualitas pelayanan dan promosi terhadap keputusan pembelian. Penelitian ini menggunakan metode penelitian kuantitatif. Pengumpulan data pada penelitian ini diperoleh melalui penyebaran kuesioner pada pengunjung McDonald's Taman Pinang. Sampel pada penelitian ini berjumlah 100 responden. Teknik pengambilan sampel yang digunakan adalah non probability sampling. Analisis data yang digunakan dalam penelitian ini menggunakan regresi linier berganda. Hasil penelitian ini disimpulkan bahwa kualitas pelayanan secara parsial berpengaruh terhadap keputusan pembelian pada dengan hasil uji t dengan nilai signifikasi 0,780 > 0,05. Promosi secara parsial tidak berpengaruh terhadap keputusan pembelian pada dengan hasil uji t dengan nilai signifikasi o,ooo < 0,05. Sedangkan berdasarkan uji F bahwa kualitas pelayanan dan promosi berpengaruh secara simultan terhadap keputusan pembelian pada dengan hasil uji $\mathrm{F}$ dengan nilai signifikasi $0,000<0,05$.
\end{abstract}

Kata Kunci : kualitas pelayanan, promosi, keputusan pembelian

\section{ABSTRACT}

This study aims to determine and examine the effect of service quality and promotion variables on purchasing decisions. This study uses quantitative research methods. Data collection in this study was obtained through distributing questionnaires to visitors to McDonald's Taman Pinang. The sample in this study amounted to 100 respondents. The sampling technique used is non-probability sampling. Analysis of the data used in this study using multiple linear regression. The results of this study concluded that service quality partially affects purchasing decisions with the results of the $t$ test with a significance value of $0.780>0.05$. Promotion partially has no effect on purchasing decisions with the results of the $t$ test with a significance value of $0.000<0.05$. Meanwhile, based on the F test that the quality of service and promotion simultaneously affect purchasing decisions with the results of the $F$ test with a significance value of $0.000<0.05$.

Keywords: service quality, promotion, purchase decision

Diterima: 19 September 2021; Direvisi: 30 September 2021; Diterbitkan: Oktober 2021 


\section{PENDAHULUAN}

Dunia saat ini sedang mengalami masa pandemi Covid-19. Virus ini datangnya dari negara Wuhan, China pada akhir Desember 2019. Virus ini menular sangat cepat dan telah menyebar ke wilayah lain di China dan beberapa negara termasuk Indonesia. Indonesia menjadi salah satu negara yang terinfeksi virus Covid-19 yang semakin meningkat. Dilansir dari kompas.com, hingga saat ini total kasus Covid-19 di Indonesia mencapai 2.417.788 jiwa terhitung sejak kasus pertama diumumkan Presiden Joko Widodo pada 2 Maret 2020.

Pandemi virus corona atau Covid19 ini tidak hanya mengancam kesehatan yang setiap waktu dapat mengancam jiwa manusia, tetapi juga berdampak negatif terhadap sektor perekonomian, sosial, dan politik. Pandemi Covid-19 ini juga menyebabkan daya beli masyarakat menurun. Dilansir dari kompas.com, pemerintah mengakui bahwa daya beli masyarakat saat ini melemah dikarenakan pendapatannya menurun, dan penurunan pendapatan ini salah satu akibat dari pemutusan hubungan kerja sebagai dampak pandemi Covid-19. Menteri Perencanaan Pembangunan Nasional (PPN/Bappenas), Suharso Monoarfa menyebutkan bahwa daya beli masyarakat hilang sebesar Rp362 triliun. Penurunan daya beli ini sudah terlihat sejak wabah atau virus ini masuk di Indonesia pada Maret 2020. Hilangnya daya beli ini juga terjadi akibat tidak adanya perputaran ekonomi antara penjual dan pembeli di lapangan.

Hampir seluruh sektor terdampak covid-19 dan sektor ekonomi mengalami dampak yang cukup serius, tak terkecuali bisnis waralaba seperti makanan cepat saji (fast food) terpukul. Berdasarkan pilot study yang telah dilakukan oleh peneliti kepada 30 responden secara acak, rata-rata diantara mereka memilih McDonald's sebagai makanan cepat saji yang paling banyak diminati di antara makanan cepat saji yang lain, seperti KFC, AW, Pizza Hut, Richeese, Burger King, dan merek yang lain. Menghadapi situasi pandemi yang sulit ini, McDonald's mengaku saat ini tengah menerapkan strategi untuk mempertahankan bisnis. Strategi yang dilakukan McDonald's dengan melakukan pengembangan solusi digital menggandeng Youtap Indonesia untuk pemesanan yang terintegrasi untuk transaksi di kasir counter, self ordering kiosk (SOK), dan drive-thru. Cara tersebut tak hanya memudahkan dalam pelayanan kepada pelanggan, namun berdampak pada peningkatan yang signifikan untuk penggunaan non tunai pada transaksi drive-thru di masa pandemi ini.

Peneliti memilih McDonald's Taman Pinang Sidoarjo sebagai lokasi penelitian. McDonald's Taman Pinang adalah salah satu McDonald's yang terdampak pada saat pandemi dimana McDonald's ini berlokasi di tengah kota sidoarjo yang memiliki tempat strategis dan mudah dijangkau karena dekat dengan mall, hotel, dan lain-lain. Saat ini, McDonald's Taman Pinang Sidoarjo menitikberatkan pada layanan McD delivery, drive-thru dan take-away yang semuanya tanpa kontak langsung untuk mendukung langkah pemerintah dalam melakukan social distancing guna mencegah laju penyebaran Covid-19. Di McDonald's Taman Pinang Sidoarjo sendiri juga melakukan protokol kesehatan yang ketat. Saat pandemi seperti ini, McDonald's Taman Pinang Sidoarjo memberlakukan pembatasan untuk antrian pesanan. Jadi apabila antrian di dalam ruangan sudah mencapai batas maksimal maka pelanggan berikutnya diminta untuk menunggu di luar sampai antrian yang di dalam berkurang, dan apabila suhu badan pengunjung melebihi 
batas normal, maka pengunjung tidak diperbolehkan masuk. Hal tersebut dilakukan bukan hanya untuk mengurangi kerumunan pelanggan tetapi untuk memaksimalkan pelayanan dengan memberikan rasa nyaman saat pelanggan melakukan transaksi pembelian.

Berdasarkan hasil dari pilot study 30 responden mayoritas memilih kualitas pelayanan dan promosi yang dapat mempengaruhi keputusan pembelian. Hasil penelitian dari Widodo (2016) menyatakan bahwa kualitas pelayanan berpengaruh signifikan terhadap keputusan pembelian. Apabila kualitas pelayanan yang diberikan oleh pegawai semakin baik, maka tingkat keputusan pembelian akan semakin tinggi. Menurut Silvestri, Aquilani \& Ruggieri (2017) layanan akan dianggap bagus apabila pendapat melebihi harapan selaras dengan harapan layanan dan akan dianggap buruk apabila tidak sesuai dengan harapan pelanggan. Berdasarkan penelitian Mada \& Ugeng (2020) menyatakan bahwa promosi berpengaruh positif dan signifikan terhadap keputusan pembelian. Philip Kotler dan Kevin Lane dalam penelitian Ayu Mahendra (2018) mengatakan bahwa promosi sebagai salah satu kesuksesan atas suatu aktivitas pemasaran yang pada hakikatnya adalah semua kegiatan untuk menyampaikan sebuah produk maupun jasa kepada pasar tujuan untuk segera melakukan keputusan.

Pandemi ini menyebabkan banyak orang tidak keluar rumah atau sering menghabiskan waktu di rumah ,McDonald's Taman Pinang Sidoarjo memperkuat promosi penjualan dengan cara memberlakukan potongan harga untuk pembelian melalui gojek, grab, maupun layanan delivery order McDonald's Taman Pinang itu sendiri. Selain itu, McDonald's Taman Pinang juga memberlakukan promosi melalui aplikasi McDonald's Taman Pinang untuk pemesanan melalui drive-thru. Hal tersebut dilakukan untuk meminimalisir kontak langsung dengan karyawan maupun pengunjung McDonald's Taman Pinang yang lain. Setelah membeli produk, konsumen bisa merasakan puas atau tidak puas dan akan terlihat dalam perilaku pasca pembelian. Perilaku pasca pembelian merupakan tahap dalam proses pengambilan keputusan pembelian dimana konsumen mengambil tindakan lebih lanjut Setelah membeli berdasarkan kepuasan atau ketidakpuasan yang mereka rasakan. Berdasarkan jurnal yang ditulis oleh Abdul Basith dan Faris Fadhilah (2018) dengan judul "Analisis Faktor-faktor yang Mempengaruhi Keputusan Pembelian Produk pada McDonald's Taman Pinang di Jatiasih Bekasi" menyatakan bahwa sebanyak 80 konsumen merasa puas terhadap produk yang disediakan oleh McDonald. Sebanyak 20 konsumen merasa sangat puas dan tidak ada konsumen yang tidak puas atas pelayanan dan produk yang ditawarkan oleh McDonald. Hal ini menunjukkan bahwa memberikan pelayanan terbaik kepada konsumen sangat penting karena berpengaruh terhadap ekspektasi konsumen seperti cita rasa produk, tampilan produk sangat penting. Untuk itu, penelitian kualitas pelayanan dan promosi terhadap keputusan pembelian sangatlah penting.

Oleh karena itu, peneliti tertarik untuk melakukan penelitian yang berjudul "Pengaruh Kualitas Pelayanan dan Promosi terhadap Keputusan Pembelian McDonald's Taman Pinang Sidoarjo". Penelitian ini dilakukan dengan tujuan untuk mengetahui dan menganalisis diantara kualitas pelayanan dan promosi berpengaruh secara parsial terhadap keputusan pembelian dan untuk mengetahui dan menganalisis kualitas pelayanan dan promosi berpengaruh secara simultan terhadap keputusan pembelian. 
Berdasarkan latar belakang masalah yang dideskripsikan, maka rumusan masalah yang akan dikaji dalam penelitian ini difokuskan pada pembahasan, sebagai berikut :

1. Bagaimana kualitas pelayanan berpengaruh secara parsial terhadap keputusan pembelian pada McDonald's Taman Pinang Sidoarjo?

2. Bagaimana promosi berpengaruh secara parsial terhadap keputusan pembelian pada McDonald's Taman Pinang Sidoarjo?

3. Bagaimana kualitas pelayanan dan promosi berpengaruh secara simultan terhadap keputusan pembelian pada McDonald's Taman Pinang Sidoarjo?

\section{KAJIAN TEORETIK}

\section{Pemasaran}

Pemasaran merupakan tempat dimana dilakukannya kegiatan jual beli produk maupun jasa dan transaksi tukar menukar produk ataupun jasa antara penjual dan pembeli. Pemasaran adalah bagian dari strategi perusahaan di dalam melangsungkan bisnisnya yang berkaitan dengan konsumen. Budi Rahayu Tanama Putri (2017) memaparkan pemasaran adalah suatu proses sosial dan manajerial dimana individu-individu dan kelompokkelompok memperoleh apa yang mereka butuhkan dan inginkan dengan menciptakan dan saling mempertukarkan produk dan jasa serta nilai antara seseorang dengan yang lainnya.

Menurut Kotler \& Amstrong (dalam Priansa, 2017:3) menjelaskan bahwa pemasaran adalah proses sosial dan manajerial dimana individu dan kelompok memenuhi kebutuhan dan keinginan mereka dengan menciptakan, menawarkan, dan bertukar sesuatu yang bernilai dengan pihak lain. Pemasaran tidak hanya berlandaskan tentang menjual dan mengiklankan tetapi juga tentang bagaimana cara mengelola hubungan yang menguntungkan dengan konsumen.

Menurut Malau (2017:1), pemasaran merupakan suatu kegiatan transaksi tukar menukar nilai yang dimiliki oleh setiap pihak seperti pertukaran antara produk yang dipunyai oleh perusahaan melalui uang yang dipunyai oleh konsumen. Dapat disimpulkan bahwa pemasaran ialah suatu kejadian transaksi yang dilakukan penjual dan pembeli yang saling menguntungkan. Pemasaran tidak hanya tentang kegiatan jual beli produk ataupun jasa tetapi juga tentang kegiatan untuk memenuhi kebutuhan serta harapan konsumen secara melangsungkan penawaran, penciptaan serta pertukaran produk yang bernilai sehingga dapat memberikan pengaruh bagi konsumen agar mau membeli produk maupun jasa yang ditawarkan perusahaan. Hal tersebut amat penting untuk manajer pemasaran didalam memahami perilaku konsumen sehingga manajer bisa mengetahui peluang, mengidentifikasi dan menentukan segmen pasar secara tepat. Dengan hal ini, perusahaan bisa mengembangkan, menetapkan harga, mempromosikan serta mendistribusikan produk dengan semakin baik.

\section{Kualitas Pelayanan}

Menurut American Society dalam buku Kotler dan Keller (2016:156), kualitas adalah "Quality is the totality of features and characteristics of a product or service that bear on its ability to satisfy stated or implied needs". Artinya kualitas adalah keseluruhan ciri dan karakteristik produk atau jasa yang mendukung kemampuan guna memuaskan kebutuhan. Menurut Susatyo Herlambang (2016:71-72), kualitas merupakan suatu cara untuk 
mencapai tujuan yang diharapkan melalui cara yang efektif serta efisien dengan memfokuskan kepuasan konsumen. Kualitas dapat berupa produk maupun layanan yang efektif, efisien, layak, aman, dan mudah dijangkau sehingga dapat dievaluasi dan ditingkatkan terus-menerus.

Pelayanan menurut Kasmir (2017:47) adalah tindakan atau perbuatan seseorang atau suatu organisasi untuk memberikan kepuasan kepada pelanggan, sesama karyawan, dan juga pimpinan. Rusydi (2017:39) berpendapat bahwa kualitas pelayanan adalah kemampuan perusahaan dalam memberikan pelayanan terbaik yang bermutu dibandingkan dengan pesaingnya. Lewis dan Booms (dalam Tjiptono 2017:142) mengemukakan bahwa kualitas layanan bisa diartikan sebagai tolak ukur seberapa bagus tingkat layanan yang diberikan mampu sesuai dengan ekspektasi atau harapan dari pelanggan. Kualitas pelayanan merupakan cara melayani, menangani keperluan konsumen yang selaras pada keinginan konsumen.

Kualitas pelayanan merupakan hal penting yang wajib perusahaan miliki didalam menawarkan produk atau jasa karena dengan adanya kualitas pelayanan kepada konsumen, perusahaan dapat menilai kinerja yang telah dicapai. Kualitas pelayanan adalah perbandingan diantara kenyataan serta harapan konsumen, apabila kenyataan yang didapatkan melebihi yang diinginkan maka pelayanan tersebut berkualitas, sebaliknya apabila kenyataan yang diterima tidak seperti yang diinginkan maka pelayanan itu tidak berkualitas. Berkualitas tidaknya pelayanan bergantung pada kemampuan dalam memberi layanan dalam memenuhi harapan konsumen.

Perusahaan senantiasa berusaha semaksimal mungkin untuk memberikan kualitas pelayanan prima yang terbaik kepada konsumen tetap dan tidak tetap seperti sikap dan perilaku serta sopan santun berbicara antara customer service dengan konsumen, merespon dengan cepat keluhan konsumen apabila ditemukan kualitas produk tidak baik dengan cara mengganti produk yang baik, memberikan harga diskon atau harga khusus bagi konsumen tetap yang memiliki kuota penjualan lebih dari target yang ditentukan (Soehardi, 2021b) (Soehardi, 2021a).

\section{Promosi}

Menurut Kotler dan Keller dalam Simamora (2018), promosi adalah segala bentuk komunikasi yang digunakan untuk menginformasikan (to inform), membujuk (to persuade), dan mengingatkan (to remind) pasar sasaran tentang produk yang dihasilkan organisasi, individu ataupun rumah tangga. Menurut Kotler dan Keller (2016:47) promosi merupakan suatu aktivitas yang mengkomunikasikan keunggulan produk serta mempengaruhi konsumen untuk membelinya. Menurut Adam (2015) dalam Lamere (2017:53) memaparkan promosi merupakan aktivitas pemasaran guna mengkomunikasikan informasi mengenai perusahaan maupun produknya kepada konsumen yang dapat menciptakan permintaan.

Kotler dan Keller (2016:582) menjelaskan bauran pemasaran adalah promotion mix yakni :

1. Advertising, semua media berbayar seperti media cetak, media online, berbagai iklan berbayar di televisi dan lain-lain yang digunakan untuk mempromosikan produk, jasa maupun ide.

2. Sales promotion merupakan suatu kegiatan promosi jangka pendek supaya konsumen bersedia mencoba atau membeli produk yang 
ditawarkan. $\quad$ Kegiatan sales promotion seperti memberikan contoh, diskon maupun bundling kepada konsumen.

3. Events and experience, suatu kegiatan yang disponsori oleh perusahaan guna menciptakan hubungan yang saling aktif antara brand tertentu.

4. Public relations and publicity, suatu strategi yang dibuat untuk mempromosikan maupun melindungi citra produk yang dimiliki.

5. Direct marketing, suatu kegiatan promosi yang mana perusahaan melakukan percakapan langsung dengan konsumen. Hermawan (2012:192-199) mengatakan bahwa direct marketing dapat dilakukan melalui media seperti majalah, email, telemarketing dan surat kabar.

6. Interactive marketing, suatu kegiatan yang dilakukan perusahaan dengan mendekatkan diri dengan konsumen guna meningkatkan penjualan atau citra produk atau jasa. Aktivitas promosi tersebut dilangsungkan lewat sosial media yang mana konsumen dapat bertanya kepada perusahaan mengenai suatu hal yang ingin diketahui.

7. Word of mouth marketing, dialog yang dilangsungkan oleh dua orang maupun lebih tentang pengalaman membeli produk atau jasa. Menurut Kotler dan Amstrong (2012:546), kegiatan ini dilakukan oleh konsumen yang satu dengan memberikan informasi berupa produk, merek, atau jasa kepada konsumen lainnya.

8. Personal selling, interaksi langsung kepada konsumen guna melakukan presentasi, menjawab pertanyaan dan mendapatkan pembelian. Hermawan (2012:106) memaparkan penjualan personal ialah suatu kegiatan pemasaran dari produk atau jasa yang mana pemasar bertemu langsung dengan konsumen untuk menggali peluang pembelian.

\section{Keputusan Pembelian}

Schiffman dan Kanuk dalam Susana (2019:13) memaparkan keputusan dalam membeli merupakan proses memilih dua maupun lebih alternatif keputusan membeli yang artian konsumen bisa melakukan ketetapan yang ada dalam sejumlah seleksi pemilihan. Ketetapan pembelian konsumen biasanya dipengaruhi oleh perilaku konsumen. Konsumen biasanya melakukan sistem maupun langkah saat mengambil keputusan saat membeli suatu produk. Menurut Kotler dan Gary Armstrong dalam Ayu Vidya (2019:14), ada lima langkah sistem membeli yaitu :

1. Pemahaman keperluan

Tingkatan ini merupakan tahapan awal dalam sistem ketetapan konsumen. Dalam tahapan pengenalan kebutuhan, konsumen menyadari kebutuhan atau masalah dalam suatu produk tersebut.

2. Penelusuran informasi

Pada tahapan tersebut, pelanggan perlu menelusuri informasi sangat luas mengenai produk yang hendak dibelinya. Konsumen mungkin hanya melakukan pencarian informasi secara aktif.

3. Penilaian pilihan

Pada tahapan tersebut, pelanggan memanfaatkan data untuk menilai merek barang yang akan dibelinya.

4. Keputusan pembelian

Dalam keputusan pembelian, konsumen biasanya biasanya memutuskan merek apa yang hendak dibeli.

5. Sikap setelah pembelian

Sesudah membeli produk, pelanggan hendak menempuh langkah berikutnya yang berlandaskan senang tidaknya pelanggan pada produk yang telah dibelinya. 


\section{KERANGKA KONSEPTUAL}

Wijaya dalam Ratnasari (2016:5) memaparkan bahwa kualitas pelayanan sebagai pengukur seberapa bagus tingkat layanan yang diberikan sesuai harapan konsumen. Berdasarkan penelitian dari Susana Maharani (2019) menunjukkan kualitas pelayanan berpengaruh positif dan signifikan terhadap keputusan pembelian. Menurut Kotler dan Keller (2016:47) promosi merupakan kegiatan yang mengkomunikasikan keunggulan produk serta membujuk konsumen untuk melakukan pembelian. Zulkarnaim dan Triyonowati (2015) memaparkan bahwa promosi berpengaruh positif dan signifikan terhadap keputusan pembelian karena banyaknya berbagai macam promosi yang ditawarkan akan menarik keinginan konsumen untuk melakukan pembelian.

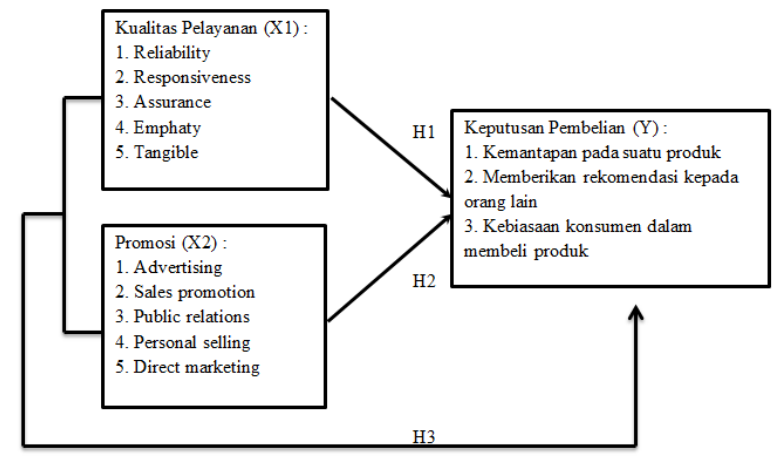

Gambar 1. Kerangka Penelitian

H1 : Kualitas pelayanan berpengaruh secara parsial terhadap keputusan pembelian McDonald's Taman Pinang Sidoarjo.

H2 : Promosi berpengaruh secara parsial terhadap keputusan pembelian McDonald's Taman Pinang Sidoarjo.

H3 : Kualitas pelayanan dan promosi berpengaruh secara simultan terhadap keputusan pembelian McDonald's Taman Pinang Sidoarjo.

\section{METODE PENELITIAN}

Dalam penelitian ini, peneliti menggunakan metode penelitian kuantitatif. Menurut Nikolaus (2019:3) metode penelitian kuantitatif merupakan kegiatan pengumpulan, pengolahan, analisis, dan penyajian data berdasarkan jumlah atau banyaknya yang dilakukan secara objektif untuk memecahkan suatu persoalan atau menguji suatu hipotesis untuk mengembangkan prinsip-prinsip umum. Penelitian ini dilakukan di McDonald's Taman Pinang Sidoarjo, tepatnya berada di Jl. Pahlawan No.1, Jetis, Lemah Putro, Kec. Sidoarjo, Kabupaten Sidoarjo, Jawa Timur 61213. Penelitian ini dilaksanakan pada bulan Februari 2021 - Juli 2021.

\section{Teknik Pengumpulan Data}

Teknik pengumpulan data yang digunakan dalam penelitian ini yaitu melalui angket atau kuesioner, diperoleh melalui pengumpulan data yang dilakukan dengan cara memberikan daftar pertanyaan atau pernyataan tertulis dan terstruktur yang ditujukan pada responden yaitu pengunjung McDonald's Taman Pinang. Responden lalu memilih salah satu alternatif jawaban yang sesuai dengan opininya. Dari jawaban responden melalui lembar kuesioner tersebut dapat dilakukan analisis dan pembahasan.

\section{Teknik Analisis Data}

Teknik analisa data dilakukan dengan uji validitas, reliabilitas, normalitas, multikolinearitas,

Heteroskedastisitas, regresi linier berganda, uji t dan uji F.

\section{HASIL PENELITIAN DAN PEMBAHASAN}

Hasil Uji Validitas 
Validitas data diukur dengan membandingkan $\mathrm{r}_{\text {hitung dengan }} \mathrm{r}_{\text {tabel }}(\mathrm{r}$ pearson product moment). Dengan kriteria pengujian apabila rhitung > rtabel dengan $\alpha=0,05$ maka alat ukur tersebut dinyatakan valid, dan sebaliknya apabila rhitung < rtabel maka alat ukur tersebut dinyatakan tidak valid. Untuk uji validitas dengan 100 responden maka nilai signifikansinya adalah 0,197 dan berikut hasil perhitungan uji validitas yang menggunakan bantuan SPSS versi 26.

Tabel 1. Hasil Uji Validitas Kualitas Pelayanan ( X1)

\begin{tabular}{ccccl}
\hline No & Item & rtabel & rhitung & keterangan \\
\hline 1. & $\mathrm{X} 1.1$ & 0.197 & 0,640 & Valid \\
\hline 2. & $\mathrm{X} 1.2$ & 0.197 & 0,644 & Valid \\
\hline 3. & $\mathrm{X} 1.3$ & 0.197 & 0,585 & Valid \\
\hline 4. & $\mathrm{X} 1.4$ & 0.197 & 0,625 & Valid \\
\hline 5. & $\mathrm{X} 1.5$ & 0.197 & 0,756 & Valid \\
\hline 6. & $\mathrm{X} 1.6$ & 0.197 & 0,763 & Valid \\
\hline 7. & $\mathrm{X} 1.7$ & 0.197 & 0,592 & Valid \\
\hline 8. & $\mathrm{X} 1.8$ & 0.197 & 0,529 & Valid \\
\hline 9. & $\mathrm{X} 1.9$ & 0.197 & 0,676 & Valid \\
\hline 10. & $\mathrm{X} 1.10$ & 0.197 & 0,595 & Valid \\
\hline 11. & $\mathrm{X} 1.11$ & 0.197 & 0,540 & Valid \\
\hline
\end{tabular}

Sumber: SPSS

Berdasarkan hasil uji validitas variabel Kualitas Pelayanan (X1) dapat diketahui bahwa semua item kuesioner dapat dinyatakan valid karena, nilai rhitung lebih besar dari r rabel.

Hasil Uji Validitas Promosi (X2)

\begin{tabular}{ccccc}
\hline No & Item & rtabel & rhitung & keterangan \\
\hline 1. & X2.1 & 0.197 & 0,745 & Valid \\
\hline 2. & X2.2 & 0.197 & 0,701 & Valid \\
\hline 3. & X2.3 & 0.197 & 0,692 & Valid \\
\hline 4. & X2.4 & 0.197 & 0,778 & Valid \\
\hline 5. & X2.5 & 0.197 & 0,708 & Valid \\
\hline 6. & X2.6 & 0.197 & 0,714 & Valid \\
\hline 7. & X2.7 & 0.197 & 0,760 & Valid \\
\hline 8. & X2.8 & 0.197 & 0,728 & Valid \\
\hline
\end{tabular}

Sumber: SPSS

Berdasarkan hasil uji validitas variabel Promosi (X2) dapat diketahui bahwa semua item kuesioner dapat dinyatakan valid karena, nilai rhitung lebih besar dari $\mathrm{r}_{\text {tabel. }}$

\begin{tabular}{|c|c|c|c|c|}
\hline No & Item & $\mathrm{r}_{\text {tabel }}$ & rhitung & keterangan \\
\hline 1. & Y.1 & 0.197 & 0,709 & Valid \\
\hline 2. & Y.2 & 0.197 & 0,662 & Valid \\
\hline 3. & Y.3 & 0.197 & 0,624 & Valid \\
\hline 4. & Y.4 & 0.197 & 0,764 & Valid \\
\hline 5. & Y.5 & 0.197 & 0,713 & Valid \\
\hline 6. & Y.6 & 0.197 & 0,783 & Valid \\
\hline 7. & Y.7 & 0.197 & 0,650 & Valid \\
\hline 8. & Y.8 & 0.197 & 0,794 & Valid \\
\hline
\end{tabular}

Sumber: SPSS

Berdasarkan hasil uji validitas variabel Keputusan Pembelian (Y) dapat diketahui bahwa semua item kuesioner dapat dinyatakan valid karena, nilai rhitung lebih besar dari $\mathrm{r}_{\text {tabel. }}$

\section{Hasil Uji Reliabilitas}

Pengujian reliabilitas terhadap semua item kuesioner dalam penelitian dengan menggunakan uji statistik Cronbach Alpha dengan SPSS Versi 26, dimana variabel dapat dinyatakan valid apabila nilai Cronbach Alpha lebih dari o,6o. Berdasarkan hasil uji reliabilitas pada variabel kualitas pelayanan (X1), diketahui bahwa nilai $\mathrm{r}$ Alpha sebesar $0,844>0,60$ maka dapat dikatakan kuesioner variabel kualitas pelayanan (X1) pada penelitian ini dinyatakan reliabel. Berdasarkan hasil uji reliabilitas variabel promosi (X2), diketahui bahwa nilai r Alpha sebesar o,868 > 0,60 maka dapat dikatakan kuesioner variabel promosi (X2) pada penelitian ini dinyatakan reliabel, dan berdasarkan hasil uji reliabilitas variabel keputusan pembelian (Y), diketahui bahwa nilai $\mathrm{r}$ Alpha sebesar 0,859>0,60 maka dapat dikatakan kuesioner variabel keputusan pembelian (Y) pada penelitian ini dinyatakan reliabel, sehingga dapat digunakan dalam penelitian ini.

\section{Hasil Uji Normalitas}


Berdasarkan hasil output pada hasil uji normalitas dapat diketahui nilai signifikan 0,253>0,05 maka dapat dinyatakan bahwa data penelitian ini berdistribusi normal.

\section{Hasil Uji Multikolinearitas}

Berdasarkan hasil uji multikolinearitas dapat diketahui bahwa variabel kualitas pelayanan memiliki nilai tolerance 0.557 dengan VIF 1.796, variabel promosi memiliki nilai tolerance o.557 dengan VIF 1.769. jadi, dapat disimpulkan bahwa tidak terjadi multikolinearitas dimana seluruh nilai $\mathrm{VIF}<10,00$ atau nilai tolerance $>0,10$.

\section{Hasil Uji Heteroskedastisitas}

Berdasarkan hasil uji
heteroskedastisitas pada variabel
Kualitas Pelayanan, memiliki nilai
signifikan o,780 > o,o5 maka dapat
ditarik kesimpulan bahwa tidak terjadi
heteroskedastisitas. Dan pada variabel
Promosi memiliki nilai signifikan diatas
o,ooo maka dapat ditarik kesimpulan
bahwa terjadi heteroskedastisitas.

\section{Uji Hipotesis}

\section{Analisis Linier Berganda}

Tujuan dari penerapan analisis linier berganda pada penelitian ini adalah untuk mengetahui adanya pengaruh dua variabel bebas, yaitu kualitas produk dan promosi dengan suatu variabel terikat, yaitu keputusan pembelian.

Berdasarkan hasil uji hipotesis dapat diperoleh persamaan regresi linier sebagai berikut:

$$
\begin{aligned}
& \mathrm{Y}=\mathrm{a}+\mathrm{b}_{1} X_{1}+\mathrm{b}_{2} X_{2}+e \\
& \mathrm{Y}=5,435+0,033 \mathrm{X} 1+0,726 \mathrm{X} 2+4,218
\end{aligned}
$$

Berikut adalah persamaan model regresi linier di atas sebagai berikut:
1) Nilai konstanta (a) = 5,435 merupakan besarnya pengaruh variabel bebas secara keseluruhan dengan variabel terikatnya.

2) Nilai koefisien kualitas pelayanan $(\mathrm{X} 1)=0,033$ artinya, apabila kualitas pelayanan (X1) bertambah satu, maka nilai dari keputusan pembelian (Y) akan mengalami kenaikan sebesar 0,033 dengan asumsi nilai variabel bebas lainnya adalah tetap.

3) Nilai koefisien promosi $\left(\mathrm{X}_{2}\right)=0,726$ artinya, apabila variabel promosi (X2) bertambah satu, maka nilai dari keputusan pembelian (Y) akan mengalami kenaikan sebesar o,726 dengan asumsi nilai variabel bebas lainnya adalah tetap.

Uji t

Pada variabel kualitas pelayanan, berdasarkan pada hasil uji t diketahui nilai signifikan variabel kualitas pelayanan terhadap keputusan pembelian sebesar $0,780>0,05$ atau thitung $0,281<1,988$ sehingga dapat disimpulkan H1 diterima Ho1 ditolak, kualitas pelayanan berpengaruh secara parsial terhadap keputusan pembelian pada McDonald's Taman Pinang Sidoarjo Di Masa Pandemi Covid-19. Sementara pada variabel promosi, berdasarkan pada hasil uji $t$ diketahui nilai signifikan variabel promosi terhadap keputusan pembelian sebesar 0,000 < 0,05 atau thitung $5,923>1,988$ sehingga dapat disimpulkan H1 ditolak Ho1 diterima, promosi tidak berpengaruh secara parsial terhadap keputusan pembelian pada McDonald's Taman Pinang Sidoarjo Di Masa Pandemi Covid-19.

Uji F

Uji F (simultan) bertujuan untuk menguji variabel kualitas produk (X1), dan promosi (X2) secara simultan berpengaruh terhadap keputusan pembelian (Y) pada McDonald's Taman 
Pinang Sidoarjo Di Masa Pandemi Covid19. Dengan ketentuan apabila nilai signifikansi <0,05 atau Fhitung $>\mathrm{F}_{\text {tabel, }}$ maka $\mathrm{H}_{03}$ ditolak dan $\mathrm{H}_{3}$ diterima. Berdasarkan pada hasil uji $\mathrm{F}$ diketahui nilai signifikan variabel bebas secara simultan terhadap variabel terikat adalah sebesar $0,000<0,05$ atau Fhitung $33,569>3,10$ sehingga dapat disimpulkan $\mathrm{H}_{3}$ diterima yang artinya terdapat pengaruh antara variabel kualitas produk dan promosi terhadap keputusan pembelian secara simultan terhadap keputusan pada McDonald's Taman Pinang Sidoarjo Di Masa Pandemi Covid-19

Koefisien Determinasi $\left(\mathrm{R}^{2}\right)$

Melalui hasil uji $\left(\mathrm{R}^{2}\right)$ dapat kita ketahui bahwa nilai R.Square sebesar 0,409, diartikan bahwa pengaruh variabel kualitas produk (X1) dan promosi (X2) terhadap keputusan pembelian (Y), yakni sebesar 40,9\%. Sedangkan sisanya yakni 59,1\% dijelaskan pada variabel lain yang tidak digunakan pada penelitian ini.

\section{Pembahasan}

Berdasarkan hasil pengujian secara statistik untuk mencari tahu pengaruh kualitas pelayanan dan promosi terhadap keputusan pembelian pada McDonald's Taman Pinang Sidoarjo. Berikut penjelasan hasil penelitian ini:

\section{Pengaruh Kualitas Pelayanan Terhadap Keputusan Pembelian}

Dari hasil penelitian menunjukkan bahwa kualitas pelayanan berpengaruh secara parsial terhadap keputusan pembelian pada McDonald's Taman Pinang Sidoarjo. Berdasarkan pada hasil uji t diperoleh nilai signifikan variabel kualitas pelayanan terhadap keputusan pembelian sebesar $0,780>0,05$ atau thitung $0,281<1,988$. Terlihat bahwa rata- rata konsumen wanita dengan usia 21-25 tahun memilih kualitas pelayanan sebagai faktor yang mempengaruhi keputusan pembelian, hal tersebut dikarenakan wanita lebih memperhatikan tentang bagaimana pelayanan yang diberikan restoran terutama pada saat pandemi covid19 sekarang ini. Seperti yang telah dipaparkan Okoraofo dkk (dalam Abdul, 2020: 5), bahwa wanita cenderung dipengaruhi oleh kualitas layanan yang lebih kuat dari pada pria sedangkan pria pada sisi lain lebih dipengaruhi oleh nilai ekonomis yang dirasakan dalam pembelian produk atau penggunaan jasa. Sama halnya dengan McDonald's Taman Pinang yang memberikan pelayanan terbaik terlihat dari pegawai yang terampil dan cekatan melayani konsumen, ramah dan sopan kepada konsumen, selalu mentaati protokol kesehatan dengan selalu memakai masker, mengecek suhu badan konsumen, menjaga jarak tempat duduk konsumen sehingga pelayanan yang dirasakan sesuai dengan harapan konsumen serta dapat diterima dengan baik oleh konsumen. Wijaya, Ratnasari dalam Susana (2019:13) berpendapat bahwa kualitas pelayanan adalah mengukur seberapa bagus tingkat layanan yang diberikan sesuai dengan konsumen. Memberikan pelayanan yang baik merupakan komponen nilai utama keberhasilan suatu perusahaan. Apabila harapan dan kebutuhan konsumen dapat terpenuhi melalui pelayanan, maka akan mempengaruhi kebutuhan konsumen untuk membeli produk atau jasa yang diberikan.

\section{Pengaruh Promosi Terhadap Keputusan Pembelian}

Dari hasil uji hipotesis penelitian memperlihatkan bahwa secara parsial promosi tidak berpengaruh terhadap keputusan pembelian pada McDonald's Taman Pinang Sidoarjo. Berdasarkan 
pada hasil uji t diketahui nilai signifikan variabel promosi terhadap keputusan pembelian sebesar $0,000<0,05$ atau thitung 5,923 > 1,988. Menurut Nur Eli (2021:65) promosi merupakan suatu kegiatan komunikasi antara individu atau perusahaan dengan masyarakat luas yang bertujuan untuk memperkenalkan sesuatu

(barang/jasa/merek/perusahaan)

kepada masyarakat dan sekaligus mempengaruhi masyarakat luas untuk membeli atau menggunakan produk tersebut. Meskipun promosi merupakan hal penting dalam sebuah pemasaran, tetapi tidak semua keputusan pembelian dipengaruhi promosi. Berdasarkan hasil kuesioner, menurut rata-rata responden yang merupakan pelajar atau mahasiswa promosi yang dilakukan McDonald's kurang menarik dan perlu ditingkatkan, karena menurut Terence (2003: 415) iklan yang baik (atau efektif) memuaskan beberapa pertimbangan yakni, iklan harus memperpanjang suara strategi pemasaran, periklanan yang efektif harus menyertakan sudut pandang konsumen, periklanan yang efektif harus persuasif, iklan harus menemukan cara yang unik untuk menerobos kerumunan iklan, iklan yang baik tidak pernah menjanjikan lebih dari apa yang bisa diberikan, dan iklan yang baik mencegah ide kreatif dari strategi yang berlebihan. Selanjutnya, menurut Ayu Vidya (2017: 101) hal tersebut dikarenakan, McDonald's telah memiliki nama yang besar sehingga membuat McDonald's kurang berfokus pada variabel ini. Terbukti dengan nilai hasil uji yang menyatakan bahwa variabel Promosi tidak signifikan dan positif.

\section{Pengaruh Kualitas Pelayanan dan Promosi Terhadap Keputusan Pembelian}

Dari hasil uji hipotesis penelitian memperlihatkan bahwa secara simultan variabel kualitas pelayanan dan promosi berpengaruh terhadap keputusan pembelian pada McDonald's Taman Pinang Sidoarjo. Berdasarkan pada hasil uji $\mathrm{F}$ diketahui nilai signifikan variabel bebas secara simultan terhadap variabel terikat adalah sebesar $0,000<0,05$ atau Fhitung 33,569 > 3,10. Sama halnya dengan penilaian konsumen bahwa kualitas pelayanan pada McDonald's Taman Pinang Sidoarjo pada masa pandemi covid 19 sesuai dengan harapan konsumen. Mulai dari mensterilkan tempat, menjaga jarak antar konsumen serta mengecek suhu tubuh konsumen dan memakai masker sesuai dengan protokol covid 19. Para pegawai McDonald's Taman Pinang Sidoarjo juga senantiasa tanggap dan sigap dalam melayani konsumen. Dan promosi yang diberikan pada masa pandemi sangat menarik. Sama halnya penelitian yang dilakukan oleh Jifly Kandoli (2019) menunjukkan bahwa secara simultan promosi dan kualitas layanan berpengaruh signifikan terhadap keputusan pembelian. Tjiptono dalam Laemonta dan Padmalia (2016) memaparkan konsumen merasa puas dan loyal apabila mereka mendapatkan kualitas layanan yang baik atau sesuai dengan yang diinginkan.

\section{KESIMPULAN}

Berdasarkan hasil penelitian yang telah dilakukan dan penjelasan hasil penelitian yang berkaitan dengan pengaruh kualitas pelayanan dan promosi terhadap keputusan pembelian pada McDonald's Taman Pinang Sidoarjo, maka dapat ditarik beberapa kesimpulan:

1. Variabel kualitas pelayanan secara parsial berpengaruh terhadap variabel keputusan pembelian pada McDonald's Taman Pinang Sidoarjo Di Masa Pandemi Covid-19.

2. Variabel promosi secara parsial tidak berpengaruh terhadap variabel keputusan pembelian pada McDonald's Taman Pinang Sidoarjo Di Masa Pandemi Covid-19. 
3. Variabel kualitas pelayanan dan promosi berpengaruh secara simultan terhadap keputusan pembelian pada McDonald's Taman Pinang Sidoarjo Di Masa Pandemi Covid-19.

\section{SARAN}

Berdasarkan hasil dan pengolahan penelitian yang telah diperoleh dan temuan yang dihasilkan. Adapun saran yang dapat diberikan yaitu Kualitas layanan di McDonald's Sidorajo sudah tergolong baik, sehingga perlu dipertahankan dan ditingkatkan lagi. Promosi di McDonald's Sidoarjo juga sudah tergolong baik, sehingga perlu dipertahankan. Meskipun demikian, ada beberapa hal yang masih perlu ditingkatkan, misalnya dalam iklan yang dikeluarkan melalui media sosial dan di billboard jalan dibuat lebih menarik lagi supaya bisa mempengaruhi pelanggan untuk membeli produknya.

\section{DAFTAR PUSTAKA}

Brahim, Muh. Nur Eli. Produk Kreatif dan Kewirausahaan Akuntansi dan Keuangan Lembaga SMK/MAK Kelas XI Semester 2. Yogyakarta: ANDI, 2021.

Byan Tri Pradigdo. Pengaruh Kualitas Pelayanan dan Kualitas Makan Terhadap Kepuasan Pelanggan dan Dampaknya Terhadap Niat Perilaku Pelanggan McDonald Cabang Bintara, Bekasi. Skripsi Universitas Negeri Jakarta, 2016.

Christian Soenjaya. Pengaruh Kualitas Pelayanan, Harga, dan Citra Perusahaan Terhadap Loyalitas Pelanggan Melalui Kepuasan Pelanggan Pada McDonald's Di Surabaya. Skripsi Universitas Katolik Widya Mandala Surabaya, 2014.

Eddy, dkk. Populasi, Sampel, Variabel dalam Penelitian Kedokteran.
Pekalongan: PT. Nasya Expanding Management, 2021.

Kandoli, Jifly. Analisis Pengaruh Promosi dan Kualitas Layanan Terhadap Keputusan Penggunaan Taxi Online Go-Car Oleh Mahasiswa FEB UNSRAT. Jurnal EMBA. VOL. 7, No. 3, 3458-3467. 2019.

Kotler , Philip and Kevin Lane Keller. Marketing Management, 15th Edition. Pearson Education, Inc, 2016.

Kotler, Philip and Kevin Lane Keller. Markeing Management, 15th Edition. New Jersey: Pearson Education Limited, 2016.

Laemonta, J.H., \& Padmalia, M. Pengaruh Inovasi dan Kualitas Layanan Terhadap Loyalitas Konsumen Terang Bulan Martabak 93. Jurnal Entrepreneur dan Entrepreneurship. 5(2), 1-8. 2016.

Lamere, Stefanus Maximus. Pengaruh Harga, Lokasi, Produk dan Promosi Terhadap Loyalitas Konsumen dengan Kepuasan Konsumen Sebagai Variabel Mediasi. Universitas Sanata Dharma, 2017.

Latif, Abdul. 2020. Kepuasan Konsumen Ditinjau dari Jenis Kelamin dan Frekuensi pada Mahasiswa Pengguna Transportasi Online Gojek di Kota Surakarta. Skripsi. Surakarta: Universitas Muhammadiyah Surakarta.

Lestari, Estrin Vanadianti. 2020. "Restoran Cepat Saji Terbesar di Dunia”. Diakses 09, Juni 2021. https://www.cekaja.com/info/re storan-cepat-saji-terbesar-didunia

Mada Faisal Akbar \& Ugeng Budi Haryoko. Pengaruh Promosi dan Harga Terhadap Keputusan Pembelian dan Dampaknya 
Terhadap Kepuasan Pelanggan Pada Alfamart Cabang Cikokol Tangerang. Jurnal Ekonomi Efektif. Vol. 2, No. 2. 2020.

Mahari, Susana. Pengaruh Kualitas Produk, Kualitas Pelayanan, Persepsi Harga terhadap Keputusan Pembelian Pizza Hut. IQTISHADequity 02, no. 01. 2019.

Mahendra, Ayu. Pengaruh Promosi Penjualan Terhadap Volume Penjualan Pada PT. LA Genius International Group Cabang Medan. Universitas Sumatera Utara, Fakultas Ekonomi Islam. 2018.

Nadyakarisma, Ayu Vidya. Pengaruh Kualitas Produk, Harga, dan Promosi terhadap Keputusan Pembelian (McDonald Epicentrum Plaza Festival). Skripsi Perbanas Institute Jakarta, 2017.

Ratnasari, Aprilian Dewi. Pengaruh Kualitas Produk, Harga, Lokasi dan Kualitas Pelayanan Terhadap Keputusan Pembelian di Djawi Lanbistro Coffee and Resto Surabaya. Surabaya: Universitas Negeri Surabaya.

Santoso, Singgih. Mahir Statistik Parametrik. Jakarta: PT. Elex Media Komputindo, 2019.

Shimp, Terence. A. 2003. Periklanan Promosi. Jakarta: Erlangga

Silvestri, C., Aquilani, B. \& Ruggieri, A. Service Quality and Customer Satisfaction in Thermal Tourism. Total Quality Management Journal. 29(1), 5581.

Soehardi. (2021a). Faktor Pengaruh Kualitas Pelayanan, Harga dan Kepuasan Turis di Tanjung Lesung Provinsi Banten. Jurnal Kajian Ilmiah, 21(2), 147-158. https://doi.org/http://ejurnal.u bharajaya.ac.id/index.php/JKI/ article/view/548

Soehardi, S. (2021b). Model Peningkatan
Volume Penjualan Melalui Kualitas Produk, Kualitas Pelayanan Dan Loyalitas Kopi Golda. Jurnal Manajemen Strategi Dan Aplikasi Bisnis, 4(2), 353-360. https://doi.org/http://ejournal.i mperiuminstitute.org/index.php /JMSAB/article/view/398

Susatyo Herlambang. Manajemen Pelayanan Kesehatan Rumah Sakit. Yogyakarta: Gosyen Publishing, 2016.

Widodo, Tri. Pengaruh Kelengkapan Produk dan Kualitas Pelayanan Terhadap Keputusan Pembelian. Among Makarti. Vol. 9. No. 17.

Yusfita, dkk. Pengantar Dasar Statistika Berbasis Masalah. Surabaya: CV. Jakad Media Publishing, 2020. 
129 | Pengaruh Kualitas Pelayanan Dan Promosi Terhadap Keputusan Pembelian Mcdonald's

Taman Pinang Sidoarjo Di Masa Pandemi Covid-19 